АНАЛІЗ ЕФЕКТИВНОСТІ НЕДЕРЖАВНИХ ПЕНСІЙНИХ ФОНДІВ УКРАЇНИ І НАПРЯМИ ІІЇ ПІДВИЩЕННЯ 3 УРАХУВАННЯМ ІННОВАЦІЙНИХ ПІДХОДІВ КРАЇН ЄС

\title{
ANALYSIS OF THE PERFORMANCE OF UKRAINIAN NON-GOVERNMENTAL PENSION FUNDS AND THE WAYS TO INCREASE IT DRAWING ON EU COUNTRIES INNOVATIVE APPROACHES
}

УДК 336.767:368(477)

https://doi.org/10.32843/infrastruct37-93

\section{Похилько С.В.}

к.е.н., доцент,

доцент кафедри фінансів

і підприємництва

Сумський державний університет

Миргородська В.С.

студентка

Сумський державний університет

\begin{abstract}
у статті досліджено сучасний стан пенсійної системи та системи недержавних пенсійних фондів (НПФ) України. Порівняно якісну й кількісну структури інвестиційних порторелів НПФ України та економічно розвинених країн. Проведено оцінювання ефективності управління активами НПФ за фрінансовими показниками. Наведено класисрікацію типів інвестиційних порторелів НПФ. Проведено кількісний аналіз ефективності системи НПФ за допомогою загальноекономічних фрінансових показників, зокрема загального рівня витрат, норми прибутку, коесіиієнтів чистого реального та номінального інвестиційного доходу, а також розраховано коефіцієнт знецінення пенсійних активів. Виявлено, що в Україні система НПФ є неефективною й не здатна виконати свої основні фуункції, такі як захист від інфрляuіï та приріст пенсійних внесків, а також компенсувати адміністративні витрати. Обгрунтовано важливу роль НПФ як акумуляторів і розпорядників інвестиційних ресурсів. Надано практичні рекомендації щодо підвищення ефеективності інвестиційної активності НПФ з урахуванням міжнародного досвіду.

Ключові слова: ефективність системи НПФ, загальний рівень витрат, норма прибутку, коефріцієнти чистого реального та номінального інвестиційного доходу, коефріцієнт знецінення пенсійних активів, інвестиційні інструменти, тип інвестиційного портфеля.
\end{abstract}

В статье исследовано современное состояние пенсионной системы и системы него- сударственных пенсионных фрондов (НПФ) Украины. Сравнена качественная и количественная структуры инвестиционных порторелей НПФ Украины и экономически развитых стран. Проведено оценивание эффрективности управления активами НПФ по финансовым показателям. Приведена классификация типов инвестиционных порторелей НПФ. Проведен количественный анализ эфрфективности системы НПФ с помощью общеэкономи ческих фринансовых показателей, в частности общего уровня расходов, нормы при были, коэффрициентов чистого реального и номинального инвестиционного дохода, а также рассчитан коэффрициент обесченивания пенсионных активов. Выявлено, что в Украине система НПФ является неэфрорективной и не способна выполнить свои основные фрункции, такие как защита от инфрляции и прирост пенсионных вкладов, а также компенсировать административные расходы. Обоснована важная роль НПФ как аккумуляторов и распорядителей инвестиционных ресурсов. Предоставлены практические рекомендации по повышению эфрфрективности инвестиционной активности НПФ с учетом международного опыта.

Ключевые слова: эфрфективность системы НПФ, общий уровень затрат, норма прибыли, коэфрфициенты чистого реального и номинального инвестиционного дохода, коэсрфициент обесценивания пенсионных активов, инвестиционные инструменты, тип инвестиционного портореля.

The article discusses a number of issues, affecting the financial health of non-governmental pension funds (NGPF). It has been established that the performance of non-state retirement funds in such matters as saving and growth of pension savings depend on the efficiency of the investment allocation by management companies and the changes in profitability of the types of financial market instruments used by these funds. The qualitative and quantitative structures of the investment portfolios of the Ukrainian NGPF and similar funds in economically advanced countries were compared. The classification of types of investment portfolios of NGPF is given. It has been found that Ukrainian NGPF' investments in government securities and bank deposits exceeded $90 \%$ of the portfolios, as the number of investment instruments is rather limited both at the legislative level and by the insufficient development of the financial market. The evaluation of NGPF asset management performance, using financial indicators, was carried out in the study. A quantitative analysis of the NGPF performance by means of general economic and financial indicators, in particular, total expense ratio, rate of return, net real and nominal investment income ratios and pension assets depreciation coefficient is presented. It has been determined that the income from investment activities does not cover the costs of the Ukrainian NGPF scheme such as investment intermediaries, asset management companies and pension trustees. Thus, the main factors contributing to the poor financial performance of Ukrainian NGPF are conservative structures of their investment portfolios, limited domestic investment opportunities on the financial market and relatively high level of administrative expenses. The article demonstrates that current investments under such conditions are unlikely to produce substantial returns to provide adequate pensions for retired persons in the future. The importance of lucrative investment allocation to NGPF for meaningful financial achievement is discussed in the paper. Practical recommendations, based on the successful development of EU NGPF schemes, are suggested in order to improve the productivity of the investment activity of Ukrainian NGPF.

Key words: performance of the NGPF's system, total expense ratio, rate of return, net real and nominal investment income ratios, pension assets depreciation coefficient, investment instruments, type of investment portfolio.

Постановка проблеми. Забезпечення гідного рівня життя громадян після завершення трудової діяльності $€$ одним із основних завдань соціальної політики будь-якої держави. Однак пенсійна система України перебуває у кризовому стані й потребує вжиття заходів стосовно ії активного ресрормування, спрямованих насамперед на роз- виток системи недержавних пенсійних фондів (НПФ). Реальна дохідність інвестиційних портоелів НПФ набуває від'ємних значень, тобто дохід, отриманий від інвестиційної діяльності, не покриває інсрляційних витрат. Така ситуація обумовлена домінуванням інструментів з фіксованим доходом у структурі інвестиційного портфреля. 
Аналіз останніх досліджень і публікацій. Питання есрективності системи НПФ знайшли відображення в працях вітчизняних та зарубіжних авторів, таких як А. Соловйов [5], В. Марчук [14], І. Левченко [15], С. Науменкова [16], С. Максутов [17].

Міжнародні та неурядові організації також звертають увагу на важливість підвищення ефективності системи НПФ. Наприклад, у 2019 році презентовано проєкт USAID «Tранссрормація фрінансового сектору» [8], а у 2017 році офрісом 3 фрінансового та економічного аналізу у ВРУ проведено дослідження «Оцінка ефрективності топ-5 недержавних пенсійних фондів в Україні».

Постановка завдання. Мета статті полягає у визначенні стану системи НПФ шляхом кількісного оцінювання ії ефективності за допомогою таких загальноприйнятих фрінансових показників, як коефріцієнти чистого реального та номінального інвестиційного доходу, норма прибутку, загальний рівень витрат, а також за авторською методикою оцінювання коефріцієнта знецінення пенсійних активів та якісної структури інвестиційних активів. Результати проведеного оцінювання слугуватимуть розробленню відповідних рекомендацій щодо підвищення ефрективності функціонування системи НПФ та пенсійної системи України загалом з урахуванням міжнародного досвіду.

Виклад основного матеріалу дослідження. Концепцію сучасної трирівневої пенсійної системи було започатковано у січні 2004 року з прийняттям Законів України «Про загальнообов'язкове державне пенсійне страхування» [1] та «Про недержавне пенсійне забезпечення» [2].

Нині основним джерелом доходів більшості українських пенсіонерів залишаються виплати 3 першого рівня (солідарної) системи загальнообов'язкового пенсійного державного страхування, яка перебуває у кризовому стані й не спроможна забезпечити гідний рівень життя громадян після завершення активної трудової діяльності. Станом на 1 липня 2019 року коефіцієнт заміщення пенсією втраченого заробітку, розрахований за показниками середньомісячної пенсії та середньомісячної заробітної плати, становив $27 \%$ [3; 4]. Таке значення не є достатнім і не відповідає рекомендаціям МОП, за якими нормативне значення показника має бути не нижчим 40\% [5, с. 57].

Запровадження другого рівня пенсійної системи, а саме накопичувальної системи загальнообов'язкового державного пенсійного страхування [1], систематично відтерміновується. Міністерством соціальної політики заплановано введення цього рівня в дію 1 січня 2020 року [6].

Виплати 3 третього рівня пенсійної системи, а саме системи недержавного пенсійного забезпечення [2], не стали сьогодні додатковим джерелом доходу для пенсіонерів. Станом на 31 грудня
2018 року на ринку працювали лише 62 НПФ та 22 адміністратори пенсійних фондів [7]. Загальна сума накопичених пенсійних активів становила 2 754,2 млн. грн., тобто у розрахунку на одного учасника НПФ пенсійні активи становлять 3210 грн. [8].

До системи недержавного пенсійного забезпечення було залучено 855300 учасників, що становить лише 5\% ринку праці в Україні. Більшість наявних учасників НПФ складають працівники, пенсійні плани яких фінансують їхні роботодавці, а самі вони не поповнюють свої пенсійні рахунки [7].

Станом на 31 грудня 2018 року роботодавці сплатили 91\% (1 827,7 млн. грн.) загальної суми накопичених пенсійних внесків, а решту, тобто 9\% (172,8 млн. грн.), - найняті працівники та приватні підприємці [7].

Недостатня зацікавленість у майбутніх пенсійних заощадженнях зумовлена зниженням реального рівня доходів населення, відсутністю надійних фрінансових інструментів для інвестування пенсійних активів НПФ, загальною недовірою до фрінансових установ, а також нестачею необхідної інорормації [8].

Більшість (54\%) учасників третього рівня сконцентрована лише в двох НПФ, а саме у професійному НПФ «Магістраль» [9] Профресійної спілки залізничників і транспортних будівельників Державної адміністрації залізничного транспорту України, клієнтами якого є АТ «Укрзалізниця» та її фрілії (326 467 осіб, або 38\% усіх учасників 3 рівня) [10], та у відкритому НПФ «Європа», клієнтами якого $є$ ПАТ «Райсрайзен Банк Аваль» та TOB «Компанія з управління активами «Європа»» (133 790 осіб, або 16\% усіх учасників) [9; 11], які $\epsilon$ монополістами на ринку НПФ. На рахунок одного учасника НПФ «Магістраль» у середньому покладено лише 118 грн., а НПФ «Європа» - 215 грн. (станом на 31 грудня 2018 року). Така ситуація спостерігається з причини того, що відповідальні роботодавці опікуються своїми працівниками й сплачують внески до НПФ за досвідом країн $€ С$, забезпечуючи їм гідну старість. Інші роботодавці $\epsilon$ недостатньо вмотивованими для використання цих інновацій, що спричинено податковим тиском з боку держави. Зокрема, ПФУ є монополістом у пенсійній системі, а також адміністратором ЄСВ у розмірі $22 \%$, тоді як у країнах $Є С$ проводять політику стримування росту розмірів державних пенсій i, відповідно, зменшення розміру внеску до державних пенсійних фрондів.

Діяльність органів державної влади також спрямована на заохочення роботодавців до інноваційної діяльності, зокрема за працевлаштування неконкурентоспроможних осіб роботодавці отримують відшкодування сплаченого ЄСВ за кожного такого працівника [12]. Ці кошти можуть бути спрямовані в систему НПФ. 
Сума пенсійних виплат із системи НПФ безпосередньо залежить від результатів інвестиційної діяльності фондів. Задля захисту заощаджень учасників у багатьох країнах держава зазвичай дуже жорстко регулює діяльність пенсійних фондів, що негативно впливає на їхню дохідність, адже перевага віддається активам з низьким рівнем ризику й дохідності.

У ситуації, що склалася, доцільно звернутися до досвіду розвинених країн, які досягли успішних результатів у побудові ефективних пенсійних систем. Порівняння структури інвестування пенсійних коштів НПФ Австрії, Естонії, Литви, Німеччини, Польщі, Румунії, Словаччини, Словенії, Угорщини, Фінляндії, Чехії, тобто країн ЄС, і України показує, що в зазначених країнах для інвестування вибирають облігації, які є безпечним та середньодохідним інвестиційним інструментом (рис. 1). Причому в 10 країнах 312 частка облігацій була вищою, ніж в Україні (10,9\%). Найбільшою частка облігацій у портселі пенсійних коштів є в Чехії (75,9\%), найменшою і меншою, ніж в Україні, - в Польщі (9,2\%).

У п'яти країнах (Австрія, Естонія, Литва, Польща, Фінляндія) 30\% активів інвестовано в акції, тоді як в Україні в акції інвестовано лише $1,6 \%$, що спричинено їх високою ризиковістю на національному фрінансовому ринку. При цьому в Чехії, де акції складають найменшу частку в портфрелі пенсійних коштів, цей показник нижче 0,5\%, бо НПФ цієї країни віддають перевагу облігаціям (75,9\%). Інвестування у грошові кошти та депозити серед країн $€ C$ не перевищує $20,5 \%$ (Чехія), тоді як в Україні воно становить більше $30 \%$. Така ситуація $є$ наслідком того, що фондовий ринок у нашій країні не став повноцінним засобом акумуляції інвестиційних коштів та їх перерозподілу.

Проаналізувавши структуру інвестиційних інструментів НПФ України та розвинених країн, можемо зробити висновок, що НПФ України проводять стриману інвестиційну політику, обумовлену нерозвинутим фрінансовим ринком, як наслідок, відсутністю інвестиційних інструментів, які $є$ надійними й мають належний рівень дохідності (граничний рівень витрат, встановлений регулятором на рівні 7\%, є завищеним, а реальна дохідність системи за досліджуваний період нижче за інфрляцію [8]) на противагу НПФ розвинених країн, які повністю використовують широке коло інвестиційних можливостей для збереження та примноження страхових внесків майбутніх бенефріціарів, в результаті чого мають більш стійкі пенсійні системи.

Розглянемо детально структуру інвестованих пенсійних активів НПФ України (рис. 2).

НПФ України вибирають для інвестування переважно 2 види інструментів фрінансового ринку, а саме державні цінні папери (1 263,5 млн. грн., або 46,0\%, станом на 31 грудня 2018 року) та банківські депозити (985,5 млн. грн., або 35,9\%), що спричинено низькими загальноекономічними показниками України, нерозвинутими ринками капіталу й відсутністю належних та надійних можливостей для інвестування. Інвестиції в облігації українських підприємств становили лише 298,6 млн. грн., або 10,9\%, в об'єкти нерухомості 47,3 млн. грн., або 1,7\%, а в акції українських та іноземних емітентів - 47,5 млн. грн., або 1,7\% [7].

У 2018 році інвестиції в державні цінні папери та банківські депозити перевищили 90\% порторелів НПФ, бо кількість інвестиційних інструментів досить обмежена як на законодавчому рівні, так і недостатньою розвиненістю фінансового ринку (акції $є$ вкрай ризиковим інвестиційним інструментом). В інших країнах консервативні низько дохідні види активів (державні цінні папери та банківські

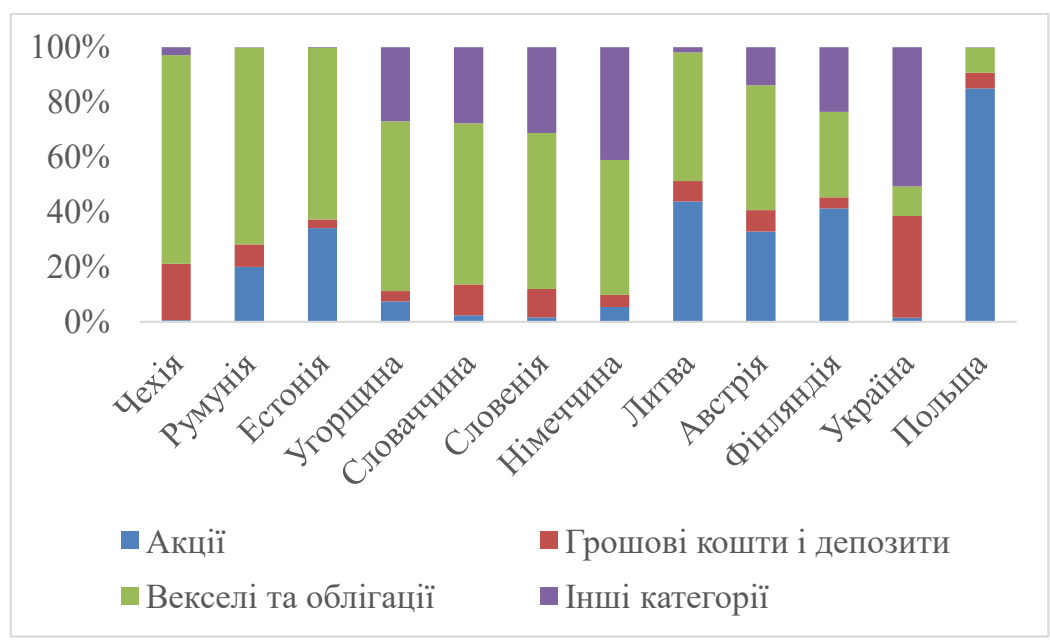

Рис. 1. Структура інвестованих пенсійних активів НПФ країн ЄС за різними напрямами інвестування на кінець 2018 року

Джерело: розроблено авторами на основі [13] 
депозити) асоціюються 3 рахунками осіб передпенсійного віку, яким не дозволено приймати підвищений ризик, а не тих, хто ще перебуває в активній, накопичувальній стадії своєї трудової діяльності (табл. 1).

3 огляду на те, що НПФ є непідприємницькими товариствами, що мають статус неприбуткових організацій, головною метою їх аналізу та оцінювання $€$ визначення ступеня есрективності фрормування пенсійних накопичень і, відповідно, здатності забезпечити своїх бенефіціарів пенсійними виплатами за рахунок вдалих інвестицій. Аналізу- вання та оцінювання НПФ здійснюються за показниками, що характеризують їх діяльність щодо фрінансового стану та результатів діяльності НПФ.

До фрінансових показників діяльності НПФ належать:

1) коефріцієнти чистого реального (за вирахуванням інфрляції) та номінального інвестиційного доходу (есрективність вкладання коштів в НПФ) $[16$, c. 13]:

$$
Д_{С 3}=\frac{\sum_{i=1}^{N}\left(4 B A_{i} \times 34 B O_{i}\right)}{\sum_{i=1}^{N} 4 B A_{i}},
$$

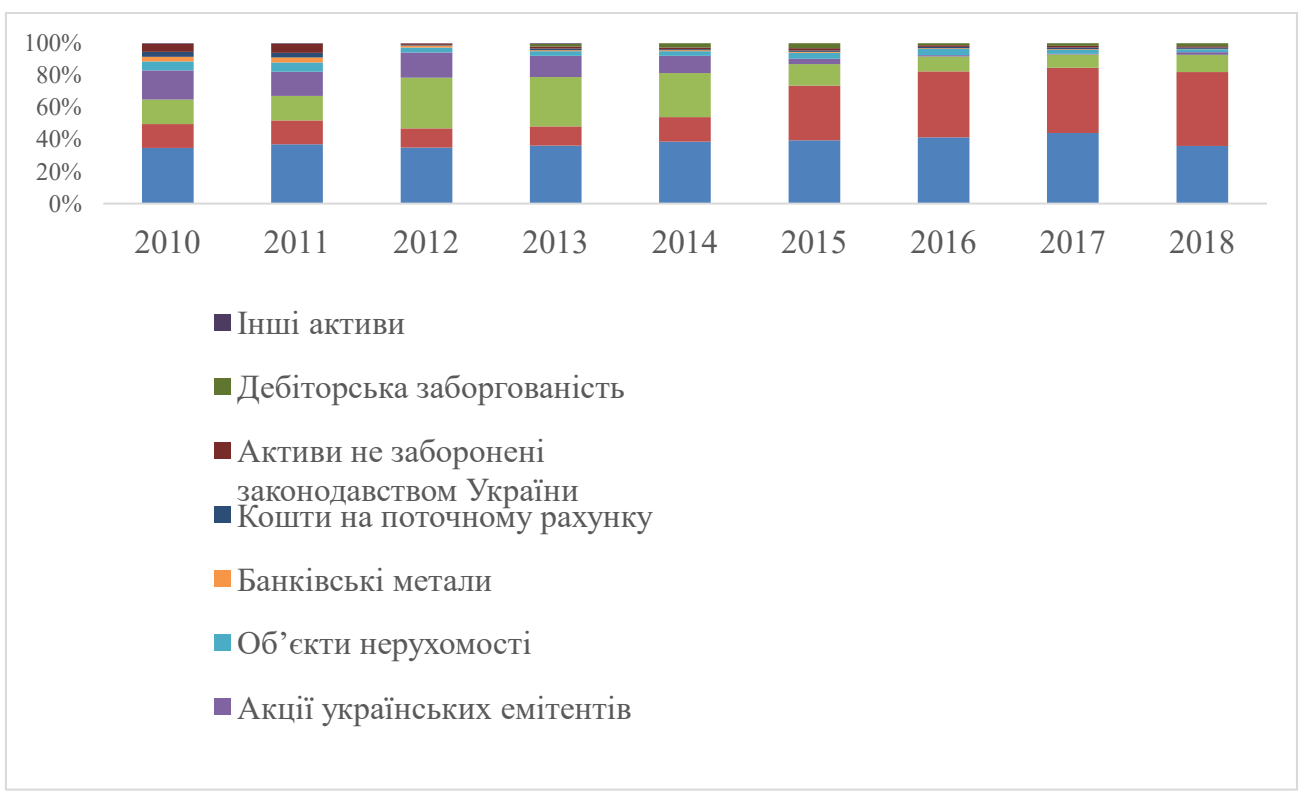

Рис. 2. Структура інвестованих пенсійних активів НПФ України за різними напрямами інвестування за 2010-2018 роки

Джерело: розроблено авторами на основі [7; 14]

Типи інвестиційних портфелів НПФ за країнами ЄС та України

\begin{tabular}{|c|c|c|}
\hline Тип портфеля & Активи & Країни \\
\hline \multirow{4}{*}{$\begin{array}{c}\text { Найбільш } \\
\text { агресивний }\end{array}$} & Акції - 40\% & \multirow{4}{*}{$\begin{array}{c}\text { Литва, Фінляндія, } \\
\text { Польща }\end{array}$} \\
\hline & Облігації підприємств - 25\%, муніципальні та державні - 15\% & \\
\hline & Депозити - 15\% & \\
\hline & Інші активи - 5\% & \\
\hline \multirow{4}{*}{$\begin{array}{c}\text { Помірно } \\
\text { агресивний }\end{array}$} & Акції - 30\% & \multirow{4}{*}{ Австрія, Естонія } \\
\hline & Облігації підприємств - 25\%, муніципальні та державні - 20\% & \\
\hline & Депозити - 20\% & \\
\hline & Інші активи - 5\% & \\
\hline \multirow{4}{*}{ Зважений } & Акції - 20\% & \multirow{4}{*}{$\begin{array}{c}\text { Німеччина, Румунія } \\
\text { Чехія, Словенія } \\
\text { Угорщина, Словаччина }\end{array}$} \\
\hline & Облігації підприємств - 25\%, муніципальні та державні - 20\% & \\
\hline & Депозити $-25 \%$ & \\
\hline & Інші активи - 10\% & \\
\hline \multirow{4}{*}{$\begin{array}{c}\text { Стриманий } \\
\text { (консервативний) }\end{array}$} & Акції - 10\% & \multirow{4}{*}{ Україна } \\
\hline & Облігації підприємств - 10\%, державні та муніципальні облігації - 20\% & \\
\hline & Депозити - 30\% & \\
\hline & Інші активи - 10\% & \\
\hline
\end{tabular}

Джерело: складено авторами за матеріалами джерела [15] 
де $Д_{c з}-$ середньозважений показник зміни у відсотках чистої вартості одиниці пенсійних активів накопичувальної системи загальнообов'язкового державного пенсійного страхування за розрахунковий період; $\mathrm{N}$ - кількість НПФ на останній день розрахункового періоду; ЧВА активів і-го НПФ на початок розрахункового періоду; Зчво - показник зміни чистої вартості одиниці пенсійних активів і-го НПФ;

2) норма прибутку або рентабельності інвестицій (есрективність інвестування коштів) [17, с. 19]:

$$
K_{p}=\frac{\Pi_{a}}{A},
$$

де $K_{p}-$ коесріцієнт рентабельності активів (норма прибутку); $\Pi_{a}$ - прибуток від розміщення пенсійних активів; $A$ - середня вартість активів за рік, обчислена як середня арифрметична вартості активів на початок та кінець року;

3) коефріцієнт чистих витрат або загальний рівень витрат (TER) (міра операційних витрат фрондів щодо активів) [18]:

$$
T E R=\frac{3 B_{i}}{A_{i}},
$$

де $3 B_{i}$ - загальний рівень витрат НПФ і-го періоду; $A_{i}$ - обсяг загальних активів НПФ і-го періоду.

Коефріцієнт рентабельності активів НПФ можна розрахувати за будь-який період діяльності НПФ. Цей коефіцієнт показує загальну ефрективність розміщення пенсійних активів, на відміну від коесріцієнтів чистого реального та номінального інвестиційного доходу, що характеризують зміну вартості одиниці пенсійних активів [2]. Відповідно, під час порівняння коефріцієнтів чистого номінального та реального інвестиційного доходу з коефріцієнтом рентабельності активів можна оці- нити вплив загальної ефрективності інвестування пенсійних активів на збільшення вигоди на одного учасника НПФ.

На основі наведених показників есективності діяльності НПФ за 2014-2018 роки було проведено розрахунки, результати яких представлено на рис. 3.

Протягом досліджуваного періоду учасники НПФ мали від'ємний чистий реальний інвестиційний дохід (з урахуванням інсрляції), який наприкінці 2018 року становив -1,44\% на рік (рис. 3). Однак коесріцієнт рентабельності НПФ за 2018 рік становив 64,39\%, що перевищувало рівень відсоткових ставок за банківськими депозитами (18\%) та рівень інфлляції $(9,8 \%)$ [19].

Варто зазначити, що наявні в Україні фрінансові інструменти для інвестування жорстко обмежують змогу одержання інвестиційного доходу, вищого за рівень інфрляції, та можливість диверсисрікації ризиків.

Система 3 рівня в Україні фрактично складається $з$ НПФ, які мають однакові консервативні структури порторелів і відрізняються один від одного лише розміром плати за послуги. Зокрема, до основних витрат, що відшкодовуються за рахунок пенсійних активів, належать витрати на оплату послуг 3 управління активами НПФ, що становлять $57,4 \%$ від загальної суми витрат, витрати на оплату послуг з адміністрування пенсійного фонду, що займають 28,3\%, оплата послуг зберігача, який здійснює відповідальне зберігання активів пенсійного фонду, що становить 5,6\% станом на 31 грудня 2018 року [13].

Наприклад, подібні витрати в країнах $€ C$ перебувають на рівні, що менший за 1\% [13]. Сьогодні високооплачувані працівники мають змогу

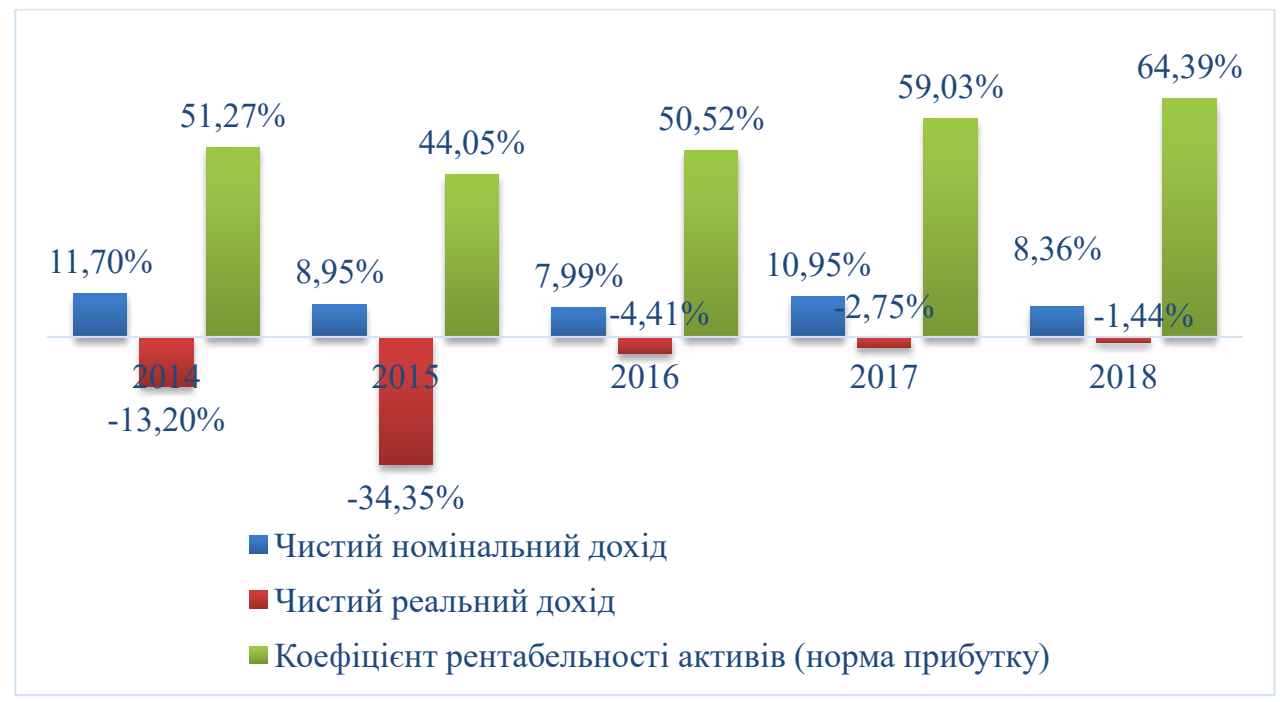

Рис. 3. Динаміка показників ефективності діяльності НПФ за 2014-2018 роки

Джерело: складено авторами за матеріалами джерела [13] 
легально заощаджувати кошти на пенсію, інвестуючи в міжнародні пасивні, але диверсифіковані пайові (індексні) інвестиційні фронди до 50000 євро на рік з раціональною платою за послуги на рівні, що становить менше 1,5\%. Іншу альтернативу інвесторам пропонують великі взаємні інвестиційні фронди в Сполучених Штатах (Fidelity, Vanguard), зокрема вкладання коштів у цінні папери 3 нульовою оплатою за послуги [8]. Із зазначеного вище випливає те, що розмістити пенсійні активи в доступних, консервативних інструментах фрінансового ринку можна без дорогого посередництва адміністраторів пенсійних фондів, компаній з управління активами та зберігачів, тобто майбутнім пенсіонерам недоцільно вкладати власні кошти у НПФ за таких високих витрат на управління.

Розглянемо такий показник ефективності недержавних пенсійних фондів, як загальний рівень витрат (total expense ratio, TER) щодо активів в управлінні (рис. 4). Загальний рівень витрат враховує операційні витрати НПФ на рекламу пенсійного плану для потенційних учасників, збирання внесків, ведення персоніфікованого обліку на індивідуальних пенсійних рахунках, переведення внесків управляючим інвестиційних фрондів, інвестування активів, оплату договорів страхування ануїтетів та забезпечення виплати ануїтетів, проведення планових аудиторських перевірок приватних пенсійних фрондів та надсилання звітів учасникам [18].

Майбутні бенефріціари звертають увагу на рівень витрат, щоби визначити, чи підходить фонд для співпраці, оскільки рівень витрат НПФ впливає на суму майбутніх виплат. Завищений рівень припустимих витрат, який дозволений на рівні 7\%, загрожує ефективній діяльності пенсійних фрондів, зменшуючи дохідність заощаджень. У 2018 році чиста реальна дохідність НПФ становила $-1,44 \%$ за рік, а загальний рівень витрат
(TER) - 11,92\%, тобто збитковість НПФ зростає до 13,36\% (рис. 3, 4).

І. Левченко [15, с. 279] пропонує використовувати показник оцінювання ефективності пенсійних капіталовкладень за кумулятивним підходом, що враховує інфляцію, оскільки це є найбільшою загрозою збереженню пенсійних коштів. Специфікою пенсійних фондів в цьому разі є те, що дохід фрормується за інвестування загальних активів фронду, зокрема внесків попередніх років і поточних внесків, і доходу, отриманого у попередніх роках. Дохідність пенсійних активів за декілька років доцільно порівнювати 3 інфляцією відповідного року:

$$
I=\frac{\sum_{i=1}^{n} A_{i} \times r_{i}}{\sum_{i=1}^{n} A_{i}},
$$

де I - коефріцієнт знецінення пенсійних активів; n - загальна кількість періодів розрахунку; $A_{i}$ - обсяг загальних активів пенсійного фронду і-го періоду; $i_{r}$ - рівень інсрляції і-го періоду.

За цією фрормулою було розраховано динаміку цього коефіцієнта протягом 2010-2018 років, що продемонстровано на рис. 5.

Загальна вартість активів НПФ наприкінці 2018 року становила 2 745,2 млн. грн., а загальна кількість одиниць пенсійних внесків 2 000,5 млн. грн. [13]. Розрахована за цими даними загальна вартість одиниці пенсійних внесків дорівнює 1,3688. Таким чином, номінальна дохідність становить 0,3688, коефіцієнт знецінення I = 0,098. В результаті у процентному вираженні як одиниці вимірювання реальна дохідність становить 27,08\%. Протягом 2010-2018 років номінальна дохідність перебувала на рівні 0,2541, а коефріцієнт знецінення пенсійних активів становив 0,1393, тобто реальна дохідність дорівнює 11,48\%.

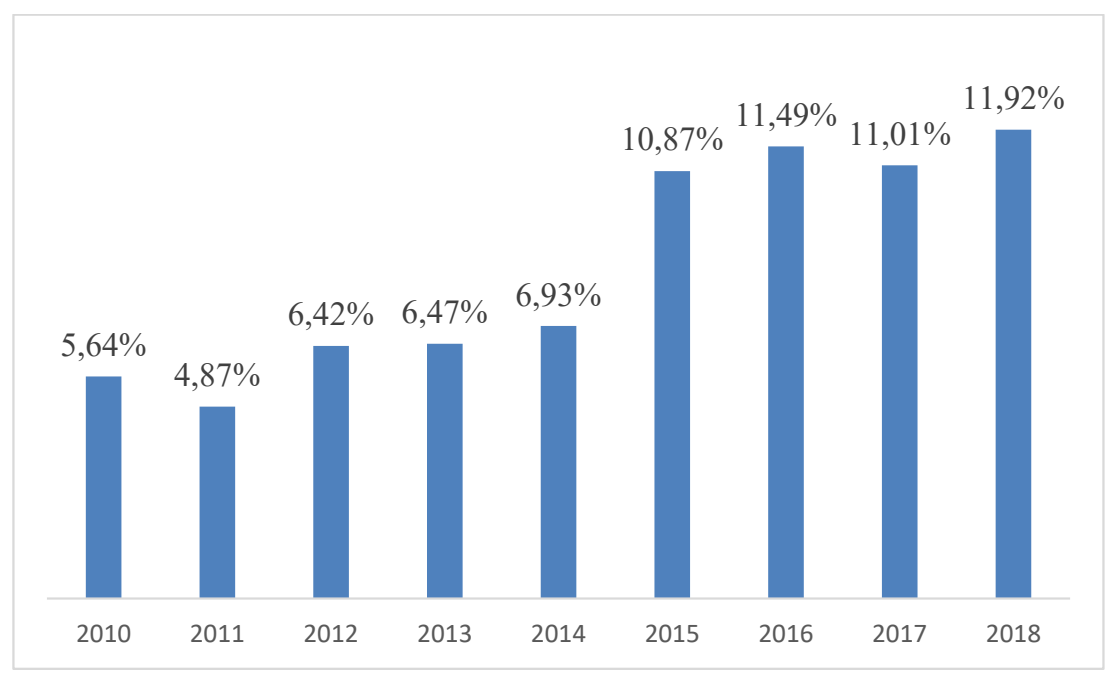

Рис. 4. Динаміка загального рівня витрат за 2010-2018 роки 


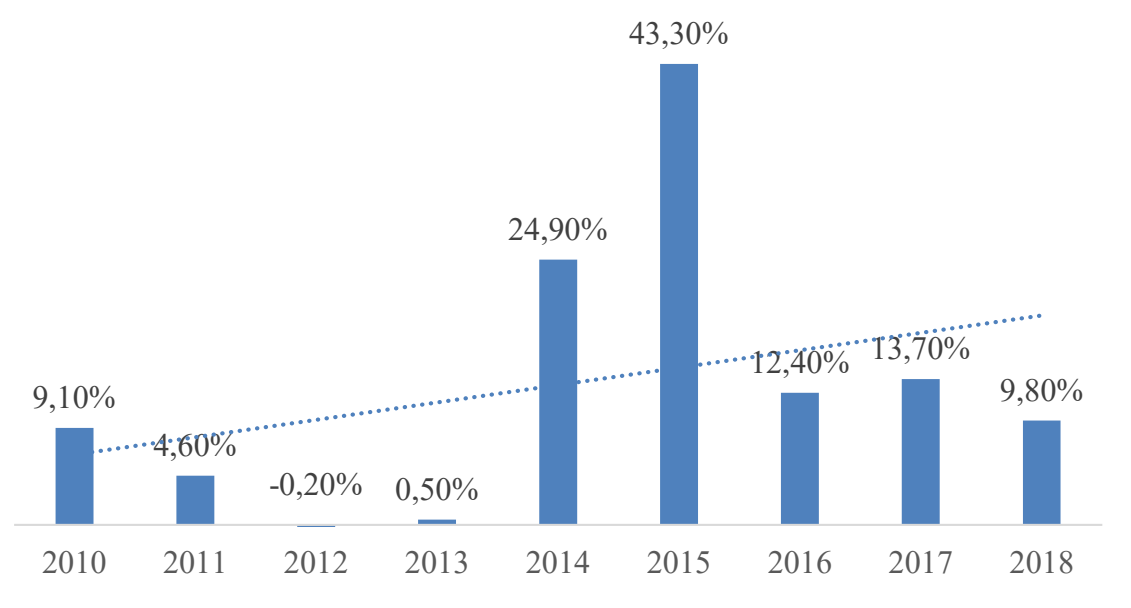

Рис. 5. Коефіцієнт знецінення пенсійних активів за 2010-2018 роки

Джерело: складено авторами за матеріалами джерел [13; 19]

Як бачимо, значення показника, отримане за авторською методикою, є прийнятним, однак суперечить розрахункам за загальноприйнятою методикою й не враховує такого вагомого фрактору, як дохідність НПФ. На нашу думку, авторська пропозиція розрахунку потребує подальшого вдосконалення й наразі $€$ неприйнятною для аналізу ефективності інвестиційної діяльності НПФ.

Висновки 3 проведеного дослідження. У 2018 році система НПФ показувала високий рівень прибутковості активів, незважаючи на від'ємний показник реальної дохідності активів учасників. Однак, оцінюючи есрективність діяльності НПФ, зважаємо на те, що ці установи мають у розпорядженні суму пенсійних активів, яка не є достатньою для проведення ефективної інвестиційної політики й побудови збалансованої структури інвестиційного портфеля. Також законодавчо жорстко регламентовано напрями розміщення коштів НПФ, визначено граничні межі інвестування в цінні папери, відсутня диверсифікованість фрінансового ринку.

Для реформування системи НПФ і забезпечення ії ефективного функціонування доцільно вжити таких заходів:

- проведення масштабної національної рекламної кампанії серед населення щодо диверсифікації майбутніх джерел доходу в пенсійному віці;

- заохочення роботодавців, які очолюють підприємства, організації, установи, які можуть виступати вкладниками й засновниками НПФ, шляхом пільгового оподаткування;

- розширення напрямів інвестування пенсійних активів шляхом створення нових державних фрінансових інструментів, номінал яких коригується відповідно до рівня інфрляції; зміна вимог щодо структури інвестиційних порторелів НПФ шляхом зменшення дозволених обсягів інвестування в банківські депозити та державні цінні папери; збільшення частки облігацій та акцій підприємств;

- міжнародне співробітництво стосовно системи НПФ, яке полягатиме в обміні позитивним досвідом з економічно розвиненими країнами та застосуванням його в Україні.

Впровадження системи НПФ на повну потужність в Україні суттєво розширить можливості для виходу з кризи солідарного рівня пенсійної системи, сприятиме підвищенню добробуту як майбутніх пенсіонерів, так і тих, хто завершив активну трудову діяльність, стимулюватиме розвиток фрінансового ринку та економіки нашої країни загалом.

\section{БІБЛІОГРАФІЧНИЙ СПИСОК:}

1. Про загальнообов'язкове державне пенсійне страхування : Закон України від 9 липня 2003 року № 1058-IV. URL: http://zakon5.rada.gov.ua/laws/show/ 1058-15/page (дата звернення: 04.11.2019).

2. Про недержавне пенсійне забезпечення: Закон України від 9 липня 2003 року № 1057-IV. URL: https://zakon.rada.gov.ua/laws/show/1057-15 (дата звернення: 04.11.2019).

3. Державна служба статистики України. URL: www.ukrstat.gov.ua (дата звернення: 11.11.2019).

4. Пенсійний фонд України. URL: http://pfu.gov.ua (дата звернення: 11.11.2019).

5. Соловьев А. Коэффрициент замещения трудовой пенсии: конорликт макроэкономических и социальных целей. Экономическая наука современной Poсcuu. 2014. № 3 (66). C. 56-67. URL: http:// cyberleninka.ru/article/n/koeffitsient-zamescheniyatrudovoy-pensii-konflikt-makroekonomicheskih-isotsialnyhtseley (дата звернення: 04.11.2019).

6. Міністерство соціальної політики України. URL: https://www.msp.gov.ua (дата звернення: 11.11.2019).

7. Національна комісія, що здійснює державне регулювання у сорері ринків фрінансових послуг. URL: https://www.nfp.gov.ua (дата звернення: 15.11.2019). 
8. Недержавне пенсійне забезпечення в Україні: оцінка та рекомендації. Проєкт USAID «Tрансформація фрінансового сектору». 2019. URL: http://www.fst-ua.info/wp-content/uploads/2019/07/ Voluntary_Private_Pensions_in_Ukraine-Assessment jul2019_ua.pdf (дата звернення: 04.11.2019).

9. Національна асоціація НПФ України та адміністраторів HПФ. URL: https://www.napfa.com.ua (дата звернення: 15.11.2019).

10. ТОВ «Адміністратор пенсійного фронду «Центр персоніфрікованого обліку»». URL: https://acpo.com.ua/ index.php (дата звернення: 15.11.2019).

11. ТОВ «Всеукраїнський адміністратор пенсійних фрондів». URL: https://www.vseapf.com.ua/ua/ company.html (дата звернення: 15.11.2019).

12. Квота 3 працевлаштування неконкурентоспроможних осіб. Інтерактивна бухгалтерія. 2013. URL: https://interbuh.com.ua/ru/documents/ oneanalytics/6093 (дата звернення: 20.11.2019).

13. Global pension statistics. URL: http://www.oecd.org/ daf/fin/private-pensions/globalpensionstatistics.htm (дата звернення: 11.11.2019).

14. Марчук В., Воробйова В. Аналіз діяльності та прогнозування активів недержавних пенсійних фрондів України. Ефрективна економіка. 2012. № 8.

15. Левченко І. Розвиток інвестиційної діяльності недержавних пенсійних фрондів та методика оцінки її ефективності. Фінансово-кредитна діяльність: проблеми теорії та практики. 2011. № 2 (11). С. 275-280.

16. Науменкова С. Функціонування недержавних пенсійних фондів на ринку фрінансових послуг України. Фінанси України. 2010. № 4 (173). С. 3-16.

17. Максутов С. Учет операций в негосударственном пенсионном фронде. Вестник бухгалтера и аудитора Украины. 2006. № 13/14. С. 16-25.

18. Hayes A. Total Expense Ratio (TER). Investopedia. 2019. URL: https://www.investopedia. com/terms/t/ter.asp (дата звернення: 20.11.2019).

19. Міністерство фрінансів України. URL: http:// index.minfin.com.ua (дата звернення: 26.11.2019).

\section{REFERENCES:}

1. Pro zahalnooboviazkove derzhavne pensiine strakhuvannia : Zakon Ukrainy [On Mandatory State Pension Insurance: Law of Ukraine]. Available at: http://zakon5.rada.gov.ua/laws/show/1058-15/page (accessed 04 November 2019).

2. Pro nederzhavne pensiine zabezpechennia Zakon Ukrainy [On Non-State Pension Provision: Law of Ukraine]. Available at: https://zakon.rada.gov.ua/laws/ show/1057-15 (accessed 04 November 2019).

3. Derzhavna sluzhba statystyky Ukrainy [State Statistics Service of Ukraine]. Available at: www.ukrstat.gov.ua (accessed 11 November 2019).

4. Pensiinyi fond Ukrainy [Pension Fund of Ukraine]. Available at: http://pfu.gov.ua (accessed 11 November 2019).

5. Solov'ev A. (2014) Koeffitsient zameshcheniya trudovoy pensii: konflikt makroekonomicheskikh sotsial'nykh tseley [Replacement Rate of Retirement Pension: the Conflict of Macroeconomic and Social Objectives]. Jekonomicheskaja nauka sovremennoj Rossii (electronic journal), vol. 3, no. 66, pp. 56-67. Available at: http://cyberleninka.ru/article/n/koeffitsient-zamescheniya- trudovoy-pensii-konfliktmakroekonomicheskih-i-sotsialnyh-tseley (accessed 4 November 2019).

6. Ministerstvo sotsialnoi polityky Ukrainy [Ministry of Social Policy of Ukraine]. Available at: https:// www.msp.gov.ua (accessed: 11 November 2019).

7. Natsionalna komisiia, shcho zdiisniuie derzhavne rehuliuvannia u sferi rynkiv finansovykh posluh [The National Commission for State Regulation of Financial Services Markets]. Available at: https://www.nfp.gov.ua (accessed 15 November 2019).

8. Nederzhavne pensiine zabezpechennia v Ukraini: otsinka ta rekomendatsii [Voluntary private pensions in Ukraine: Assessment and Recommendations]. (2019) Proekt USAID "Transformatsiia finansovoho sektoru". Available at: http://www.fst-ua. info/wp-content/uploads/2019/07/Voluntary_Private Pensions_in_Ukraine-Assessment_jul2019_ua.pdf (accessed 4 November 2019).

9. Natsionalna asotsiatsiia NPF Ukrainy ta administratoriv NPF [National Association of NSPF of Ukraine and NSPF Administrators]. Available at: https:// www.napfa.com.ua (accessed 15 November 2019).

10. TOV "Administrator pensiinoho fondu "Tsentr personifikovanoho obliku"' [LLC "Administrator of Pension Fund "Center of Personification processing"'. Administrator of Pension Fund]. Available at: https:// acpo.com.ua/index.php (accessed 15 November 2019).

11. TOV "Vseukrainskyi administrator pensiinykh fondiv" [The All-Ukrainian pension fund's administrator LTD]. Available at: https://www.vseapf.com.ua/ua/company.html (accessed 15 November 2019).

12. Kvota z pratsevlashtuvannia nekonkurentospromozhnykh osib [Employment quotas of non-competitive individuals]. (2013). Interaktyvna bukhhalteriia. Available at: https://interbuh.com.ua/ru/documents/oneanalytics/6093 (accessed: 20 November 2019).

13. Global pension statistics. Available at: http:// www.oecd.org/daf/fin/private-pensions/globalpensionstatistics.htm (accessed 11 November 2019).

14. Marchuk V., Vorobiova V. (2012) Analiz diialnosti ta prohnozuvannia aktyviv nederzhavnykh pensiinykh fondiv Ukrainy [Analysis of activity and forecasting of assets of Ukrainian NSPFs]. Efektyvna ekonomika, vol. 8.

15. Levchenko I. (2011) Rozvytok investytsiinoi diialnosti nederzhavnykh pensiinykh fondiv ta metodyka otsinky yii efektyvnosti [Development of investment activity of NSPFs and method of evaluation of its performance]. Finansovo-kredytna diialnist: problemy teorii ta praktyky (electronic journal), vol. 2 (11), pp. 275-280. (in Ukrainian)

16. Naumenkova S. (2010) Funktsionuvannia nederzhavnykh pensiinykh fondiv na rynku finansovykh posluh Ukrainy [The functioning of NSPFs in the financial services market of Ukraine]. Finansy Ukrayiny (electronic journal), vol. 4, no. 173, pp. 3-16.

17. Maksutov S. (2006) Uchet operacij v negosudarstvennom pensionnom fonde [Transaction Accounting in NSPF]. Vestnik bukhgaltera $i$ auditora Ukrainy (electronic journal), vol. 13/14, pp. 16-25.

18. Hayes A. (2019) Total Expense Ratio (TER). Investopedia. Available at: https://www.investopedia.com/ terms/t/ter.asp (accessed 20 November 2019).

19. Ministerstvo finansiv Ukrayiny [Ministry of Finance of Ukraine]. Available at: http://index.minfin.com.ua (accessed 26 November 2019). 
Pokhylko Svitlana

Candidate of Economic Sciences, Associate Professor, Senior Lecturer at Department of Finance and Entrepreneurship

Sumy State University

Myrhorodska Viktoriia

Student

Sumy State University

\section{ANALYSIS OF THE PERFORMANCE OF UKRAINIAN NON-GOVERNMENTAL PENSION FUNDS AND METHODS TO INCREASE IT DRAWING ON EU COUNTRIES INNOVATIVE APPROACHES}

The purpose of the article. The purpose of the article is to assess the financial performance of Ukrainian non-governmental pension funds (NGPFs) by quantifying their effectiveness through commonly accepted financial indicators such as total expense ratio, rate of return, net real and nominal investment income ratios, pension assets depreciation coefficient and by qualifying their investment assets structure.

Providing decent living standards for citizens after retirement is one of the fundamental social policy concerns of any state. However, the Ukrainian pension system now faces a financial crisis and requires active reform measures, primarily focused on developing the system of non-governmental pension funds.

Methodology. Methods such as statistical and graphical analysis, and comparative methods were used in carrying out the study.

Results. It has been determined that personal pension saving schemes are still not widely used in Ukraine. Although retirement benefits from private pension schemes are an additional source of income for pensioners, the main source of income for the majority of Ukrainian pensioners remains payments from the state pension system. There is a growing trend in EU countries toward increasing the proportion of retirement income that retirees receive from personal pension savings.

The composition of the investment portfolios of the Ukrainian NGPFs and pension schemes in EU countries is compared in the paper. Investment managers for the Ukrainian NGPFs invest around $90 \%$ of their funds in low yielding and safe assets such as bank deposits and government securities. Worldwide, the best pension schemes are successful managers of funds achieving high returns and are also catalysts for investment reform.

The paper uses new techniques for classification of investment portfolios. Unlike pension funds in EU countries, where moderately conservative, moderately aggressive or aggressive investment portfolios are available; Ukrainian NGPFs investment portfolios include only low yielding assets, which is why their return is extremely low. This is due to the fact that the number of investment instruments, available within Ukraine, is limited both at the legislative level and due to insufficient development of the financial market.

General economic and financial performance indicators, taking into account returns from investment activity and the level of expenses, were calculated for Ukrainian NGPFs. It was found that Ukrainian NGPFs are inefficient and unable to perform their core functions such as achieving an investment return in excess of inflation. The performance of Ukrainian NGPFs is also poor because of their high administrative expenses compared to similar pension schemes in EU countries.

Practical implications. The paper highlights the need to improve the effectiveness in three arias - the disappointing performance of Ukrainian NGPFs as managers of investment funds, the limited selection of financial instruments on the Ukrainian financial market and the regulatory framework.

Value/originality. Based on the results of the assessment, recommendations were developed to improve the financial performance of Ukrainian NGPFs and the Ukrainian pension system overall in the paper. Comparing the situation in Ukraine with that in other countries the need was identified for:

- expanding the range of financial instruments, suitable for pension funds' investments and the effective investment allocation of NGPFs assets;

- raising pension awareness and education amongst citizens;

- encouraging employers to participate in private pension schemes through taxation incentives;

- exchanging experience in the development of NGPF schemes with economically advanced countries. 